\title{
A Rare case of Bilateral ovarian dysgerminoma with Syncytiotrophoblast giant cell ; A Case report.
}

\author{
Dranjana ${ }^{1}$,Dr.kanchan Kumari ${ }^{2}$,Dr. Indrani Karmakar ${ }^{3}$, \\ Dr. Kamlesh Prasad Sinha ${ }^{4}$ \\ ${ }^{1}(\text { Ex Junior Resident },)^{2,3}(\text { Junior Resident, })^{4}($ Associate Professor, \\ Department of Pathology, Rajendra Institute of Medical Sciences, Ranchi, Jharkhand, India)
}

\begin{abstract}
Dysgerminoma is an uncommon tumor, accounting for 1-2\% of primary ovarian neoplasm and for 3$5 \%$ of ovarian malignancies.Tumor may occur at any age from infancy to old age,but most cases occur in adolescence and early adult life.Dysgerminoma occur not infrequently before puberty but is very rare after menopause.Literature states that about $2 \%$ of nonpregnant patient with dysgerminoma present with elevated serum or urine level of $\beta h C G$. Moreover,once diagnosed,it responds highly to prescribed treatment,rescuing patient from infertility and early mortality.These tumors are radiosensitive. Here we present a case of 16 year old girl presenting with abdominal lump,ascites and abdominal pain with elevated urinary and serum $\beta h C G$ levels.An abdominal USG showed bilateral ovarian mass.Bilateral oophorectomy was done and diagnosis is confirmed by histopathology.
\end{abstract}

Keywords: $\beta$ CG,dysgerminoma,ovary,syncytiotrophoblast giant cell.

\section{Introduction}

Dysgerminoma is tumor of ovary that is composed of primitive undifferentiated germ cell ${ }^{[1]}$. It is most common malignant germ cell tumor occurring in ovary and these lesions are found most commonly in adolescent and young adults ${ }^{[2]}$. In fact, approximately $60 \%$ of cases are diagnosed in patient younger than 20 years ${ }^{[3]}$.It is usually unilateral.It tends to occur more often in right ovary and bilateral involvement occurs in $10-15 \%$ of cases ${ }^{[4]}$.Much higher frequency of bilaterality is observed in patients with dysgerminoma associated with gonadoblastoma ${ }^{[5]}$.It is confined to ovary(stage1)at diagnosis in $60-80 \%$ of patient ${ }^{[6]}$. Extra ovarian spread of dysgerminoma often involves retroperitoneal and pelvic lymph node ${ }^{[7]}$. These tumor are highly radiosensitive.It is associated with elevated serum level of $\mathrm{LDH}^{[8]}$.

Dysgerminoma is characterised by their solid nature and rapid growth.Grossly it is often large $(>10 \mathrm{~cm}$ in max dimension),encapsulated with smooth,often bosselated surface ${ }^{[9]}$.It is composed of polygonal cell with abundant granular eosinophilic or clear cytoplasm and distinct cell membrane ${ }^{[10]}$.Nuclei are round,medium sized and relatively uniform with vesicular chromatin and prominent nucleoli.Mitotic figure are usually numerous.Cells grow in sheet,nest or trabeculae that are separated by fibrous septa.Lymphocytes usually present in septa and in lesser number among tumor cells. Noncaseating granuloma,syncytiotrophoblast giant cell and germinal centre formation are not uncommon.Most of these tumor have no endocrine function.A few of them produce elevated level of chorionic gonadotropin,may have syncytiotrophoblastic giant cell.Neoplastic cell express PLAP,CD117,OCT3/4,SALL4 and variably cytokeratin.

\section{Case Report}

Here we present a case of 16 year old girl presenting with abdominal lump, ascites and abdominal pain. An abdominal ultrasound showed bilateral solid ovarian mass with right ovary of size $11.5 \mathrm{~cm} \times 7 \mathrm{~cm} \times 3 \mathrm{~cm}$ and left ovary of size $20 \mathrm{~cm} \times 14 \mathrm{~cm} \times 5 \mathrm{~cm}$.

On gross examination,right ovary is of greyish brown colour with few blackish areas,surface appears irregular. (fig: 1).Left ovary is of greyish brown with bosselated surface. (fig 2).Cut section shows few nodules with firm consistency. 


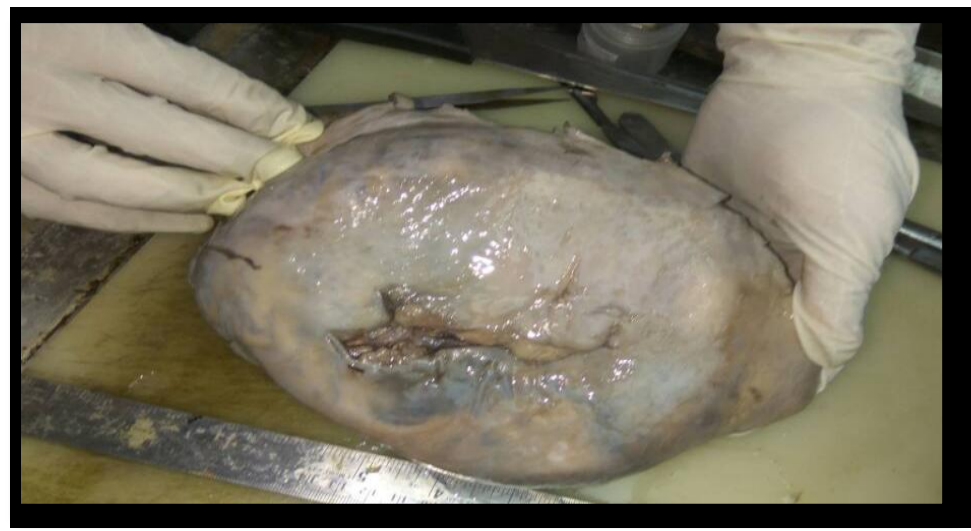

Fig 1 : Gross examination of right ovary.

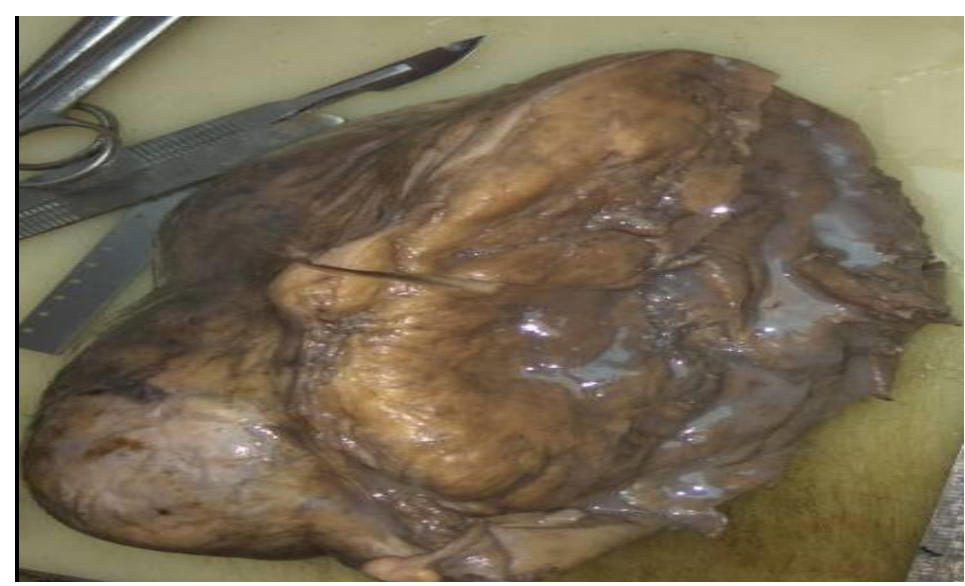

Fig 2 : Gross examination of left ovary

Histological examination shows tumor cells arranged in sheets separated by fibrous septa.Numerous lymphocytes are present in the septa and in lesser number also among tumor cells. (fig: 3).Cells are polygonal with clear cytoplasm and distinct cell membrane.Nuclei are round,medium sized and relatively uniform with vesicular chromatin and prominent nucleoli.Syncytiotrophoblast are also present among tumor cells. (fig:4).

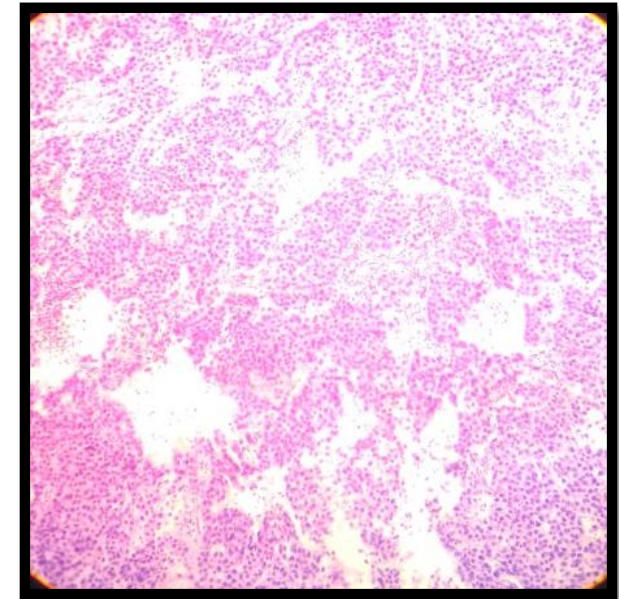

Fig 3 :Nest of tumor cells separated by septa with lymphocytes in septa.(H\&E 10X).

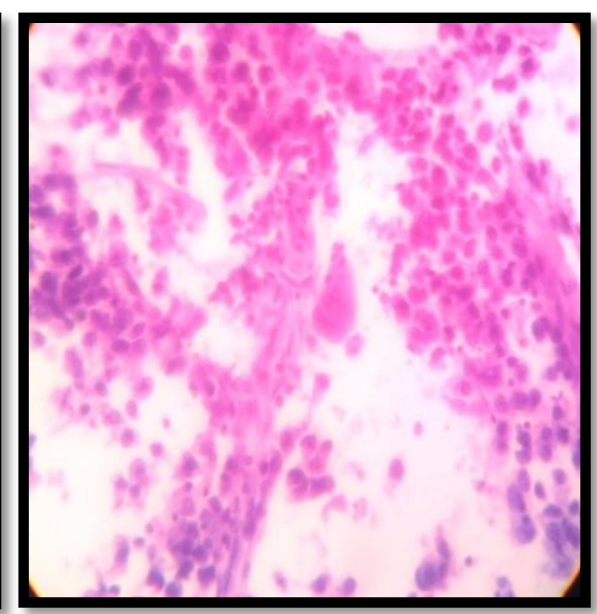

Fig 4: Nest of tumor cells containing syncytiotrophoblast giant cell.(H\&E 40X).

\section{DISCUSSION}

Zaleadek et al had described six cases of dysgerminoma with syncytiotrophoblast giant cell diagnosed on histopathology ${ }^{[11]}$.Kim et al described a single case of pure dysgerminoma with syncytiotrophoblast giant cell secreting $\beta h \mathrm{CG}^{[12]}$.Similar reports have been published by Kapp et al and Davidson ${ }^{[4]}$. 
Dysgerminoma are most common malignant germ cell tumors of ovary, comprising approximately $45 \%$ of these tumor and about $1 \%$ of all ovarian cancer $^{[13]}$.It is associated with excellent prognosis. Patient have 5 years survival rate of greater than $95 \%$ for stage $1 \mathrm{~A}$ tumor(confined to ovary) and $85 \%$ in cases of advanced stage or recurrence ${ }^{[14]}$.Clinically dysgerminoma may present as abdominal mass or with pelvic pain on pressure.Among malignant GCT of ovary, elevated $\beta$ hCG levels are most frequently observed with choriocarcinoma and embryonal carcinoma ${ }^{[15]}$. However dysgerminoma containing syncytiotrophoblast giant cells (5\% of cases)may also produce $\beta \mathrm{hCG}^{[16]}$.Pure ovarian dysgerminoma with associated elevation of $\beta$ hCG are rare $(2 \%)$ and their optimal management is clear.Although the presence of syncytiotrophoblastic giant cell alone in dysgerminoma does not affect prognosis.It is important to rule out the presence of nonseminomatous germ cell tumors.

\section{Conclusion}

Bilateral ovarian dysgerminoma is relatively uncommon but presence of syncytotrphoblast is a very rare presentation. Although it does not affect prognosis but cases should be carefully examined in patients with raised $\beta$ hCG level.

\section{References}

[1]. Michener, C.M. and Huh, W.K. (2012) Ovarian dysgerminomas. Medscape Drugs, Diseases \& Procedures. Prat J. Prat J, ed. Pathology of the Ovary. Germ cell tumors. Philadelphia, Pa: Saunders; 2004. 251-82.

[2]. Talerman A. Blaustein's Pathology of the Female Genital Tract. Kurman RJ. Germ cell tumors of the ovary. 5th ed. New York, NY: : Springer-Verlag; 2002. 967-10344.

[3]. Gimelli S, Beri S, Drabkin HA, Gambini C, Gregorio A, Fiorio P, et al. The tumor suppressor gene TRC8/RNF139 is disrupted by a constitutional balanced translocation $\mathrm{t}(8 ; 22)(\mathrm{q} 24.13 ; \mathrm{q} 11.21)$ in a young girl with dysgerminoma. Molecular Cancer. 2009. 8:52-. [Medline].

[4]. Gershenson DM, Copeland LJ, del Junco G. Second-look laparotomy in the management of malignant germ cell tumors of the ovary. Obstet Gynecol. 1986 Jun. 67(6):789-93. [Medline].

[5]. Gershenson DM, Morris M, Cangir A, Kavanagh JJ, Stringer CA, Edwards CL. Treatment of malignant germ cell tumors of the ovary with bleomycin, etoposide, and cisplatin. J ClinOncol. 1990 Apr. 8(4):715-20. [Medline]

[6]. Kim JY, Choi SL, Park IW. A case of pure dysgerminoma with syncytiotrophoblastic giant cell secreting HCG. Korean J ObstetGynecol 2003;46:469-73.

[7]. Hemlatha AL, Divya P, Mamatha R. Image-directed percutaneous FNAC of ovarian neoplasms. Indian J PatholMicrobiol 2005;48:305-9.

[8]. Kapp DS, Kohorn El, Merino Mj, LiVolsi VA. Pure dysgerminoma of the ovary with elevated serum human chorionic gonadotropin: diagnostic and therapeutic considerations. GynecolOncol 1985;20:234-44.

[9]. Zaloudek CJ, Tavassoli FA, Norris HJ. Dysgerminoma with syncytiotrophoblastic giant cells: A histologically and clinically distinctive subtype of dysgerminoma. Am J SurgPathol

[10]. Davidson MB. B-HCG-producing ovarian dysgerminoma. UgeskrLaeger 1992;154:1976-7

[11]. Ayhan A, Bildhlei I, Gunalp S, Yuee. Pure dygserminoma of the ovary: a review of 45 well staged cases. Eur J GyneaecolOncol 2000; 21(1): 98-101. 13. Dietl J, Horny HP, Ruck P, Kaiserling E. Dysgerminoma of the ovary, An immunohistochemical study of tumor-infiltrating lymphoreticular cells and tumor cells. Cancer 1993; 71(8): 2562-8. 14

[12]. Gordon A, Lipton D, Woodruff JD. Dysgerminoma a review of 158 cases from the Email Novak Gvarian tumor registry. ObstetGynecol 1981; 58 (4): 497- 504 